\title{
Tar Spot: An Understudied Disease Threatening Corn Production in the Americas
}

J. Valle-Torres, T. J. Ross, D. Plewa, M. C. Avellaneda, J. Check, M. I. Chilvers, A. P. Cruz, F. Dalla Lana,
C. Groves, C. Gongora-Canul, L. Henriquez-Dole, T. Jamann, N. Kleczewski, S. Lipps, D. Malvick,
A. G. McCoy, D. S. Mueller, P. A. Paul, C. Puerto, C. Schloemer, R. N. Raid, A. Robertson, E. M. Roggenkamp, D. L. Smith, D. E. P. Telenko, and C. D. Cruz ${ }^{\dagger}$

Keywords: fungi, field crops, etiology, epidemiology, disease development and spread, Phyllachora maydis, Monographella maydis, Coniothyrium phyllachorae, tar spot complex

Tar spot caused by Phyllachora maydis Maubl., an obligate fungus, is a major foliar disease of corn. Tar spot can reduce grain yield and quality of silage, stover, and husks in corn (Bajet et al. 1994; Hock et al. 1989; Maublanc 1904). In Latin America, economic damage of up to $50 \%$ has been documented when epidemics are severe early in corn plants' reproductive phases. $P$. maydis is endemic to Latin America, where it was first identified in Mexico in 1904 (Abbott 1931; Bajet et al. 1994; Liu 1973; Malaguti and Subero 1972; Maublanc 1904). Beginning in 2015, P. maydis appeared and has spread in the Midwest United States (U.S.) (Bissonnette 2015; Dalla Lana et al. 2019; Malvick et al. 2020; McCoy et al. 2018; Ruhl et al. 2016).

In Latin America, P. maydis is purportedly associated with two other fungi (Hock et al. 1995): Monographella maydis Müller \& Samuels, a necrophyte, and Coniothyrium phyllachorae Maubl., a fungal hyperparasite (Hock et al. 1995). However, in the U.S., only $P$. maydis has been documented in association with tar spot of corn (McCoy et al. 2019). The disease can cause corn grain yield losses ranging from 11 to $46 \%$ in Latin America (Hock et al. 1989; Pereyda-Hernández et al. 2009). Corn grain yield losses of up to 25 to $30 \%$ were recently reported in the Midwest U.S. (Mueller et al. 2018; Telenko et al. 2019). Due to a lack of information about this pathosystem and the dire threat tar spot poses to the U.S. economy, there is a pressing need for research on the biology, ecology, epidemiology, and management of the organism(s) that cause tar spot. This feature article reviews the available literature on tar spot of corn and the other species associated with this disease to help guide current and future research on this economically important pathosystem.

\section{Signs, Symptoms, Causal Agent(s), and Host Range}

Tar spot is characterized by the formation of black stromata, the fruiting bodies of $P$. maydis, on the foliage. The stromata resemble

${ }^{\dagger}$ Corresponding author: C. D. Cruz; cd-cruz@purdue.edu

J. Valle-Torres, T. J. Ross, and D. Plewa are shared first authors on this work.

Funding: Purdue University; Indiana Corn Marketing Council

The author(s) declare no conflict of interest.

Accepted for publication 3 June 2020

(C) 2020 The American Phytopathological Society spots of tar (Fig. 1). Like other species in the genus, $P$. maydis is an obligate biotroph, requiring a living host to grow and reproduce (Cannon 1991). In fields with infested corn residue, initial signs and symptoms of tar spot may appear in the lower canopy of the corn plant (Bajet et al. 1994). In the U.S., "top down" patterns of disease frequently occur in new locations, suggesting long distance transmission of inoculum. However, plants of any age, leaves, leaf sheaths, and husks are susceptible to infection (Bajet et al. 1994; Hock et al. 1995)

$P$. maydis infection results in the development of glossy structures (mass of black fungal tissues) known as stromata (Fig. 2) (Carson 1999; CIMMYT 2003; Hock et al. 1995). Stromata are embedded in host tissue and scattered across or clustered on both leaf surfaces, occasionally coalescing into stripes (Liu 1973). Stromata are sometimes enclosed by brown, elliptical, necrotic halos referred to as "fisheye lesions" (Fig. 3). In severe cases, necrotic halos coalesce, causing extensive necrosis and leaf blight leading to premature senescence and death of plants (Carson 1999; Ceballos and Deutsch 1992; Hock et al. 1995). The host range for P. maydis appears to be restricted to Zea mays (Cline 2019), although other Phyllachora species cause tar spot on a wide range of grass species and other hosts (Parbery 1967, 1971).

Older literature indicated that fisheye lesions were always associated with the presence of the fungus Monographella maydis (Bajet et al. 1994; Ceballos and Deutsch 1992; Hock et al. 1992, 1995; Müller and Samuels 1984). However, these results were based on limited surveys. In Müller and Samuels (1984), M. maydis was described as being associated with fisheye lesions. However, identification was based solely on morphological characteristics, and no voucher specimens were deposited for posterity. Additional research on $M$. maydis failed to provide evidence confirming the presence and appropriate identification of the pathogen, and again, no voucher specimens were deposited. In Latin America, infection by $P$. maydis or M. maydis alone was initially considered to be of minor importance (Müller and Samuels 1984; Hock 1989). Dual infection with $M$. maydis and $P$. maydis was implicated in significant leaf necrosis and yield loss (CIMMYT 2003). In field conditions where both fungi were present, researchers speculated that $M$. maydis entered plants following infection by $P$. maydis, and subsequently produced a toxin that caused the fisheye lesions. However, situations have been reported in Mexico, Ecuador, Honduras, and the U.S. where the fisheye symptoms were present but M. maydis was absent (Ceballos and Deutsch 1992; McCoy et al. 2019; Ruhl et al. 2016). McCoy et al. (2019) carried out a next generation sequencing analysis to determine 
if M. maydis was present in fisheye lesions of samples collected in Michigan, and to identify the different fungi found in tar spot lesions with and without fisheye symptoms. Two Microdochium spp. operational taxonomic units (OTU) were identified; however, neither was abundant nor associated consistently with fisheye symptoms. No evidence of M. maydis was found among U.S.-associated fisheye samples, which suggested that $M$. maydis is not necessary for developing fisheye symptoms in tar spot of corn in the U.S. (McCoy et al. 2019).

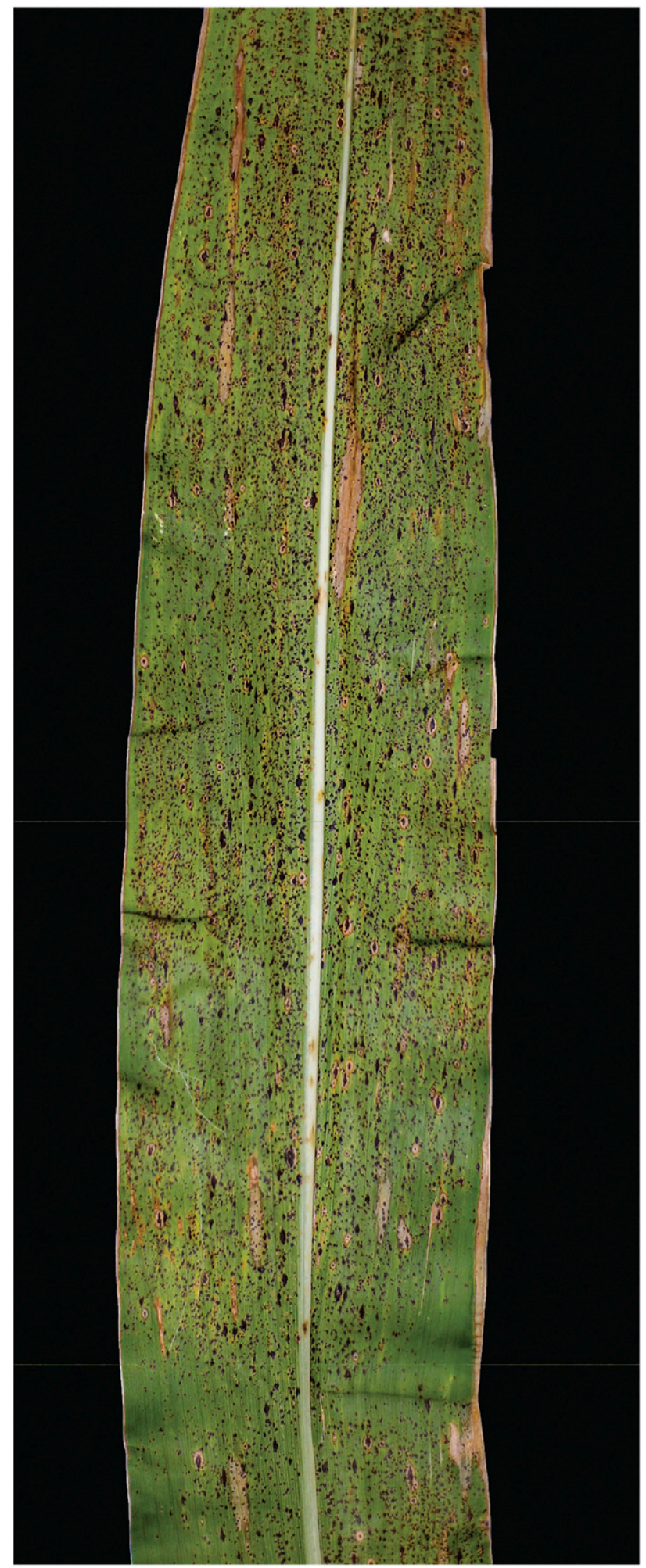

Fig. 1. Fungal fruiting bodies of Phyllachora maydis on the foliage resemble spots of tar.
Another fungus, Coniothyrium phyllachorae Maubl., was also speculated to be associated with stroma of P. maydis (Maublanc 1904; Müller and Samuels 1984). C. phyllachorae is a fungal hyperparasite of $P$. maydis that destroys perithecia produced by $P$. maydis (Maublanc 1904), and this characteristic suggests that $C$. phyllachorae may be used as a biological control for tar spot rather than being responsible for tar spot symptoms. However, this potential management strategy has not been tested (Hock et al. 1995). The observation that tar spot lesions containing $C$. phyllachorae are usually smaller than lesions containing M. maydis (Hock et al. 1989, 1995) has not been explained.

\section{Biology of Spores}

P. maydis is an ascomycete, producing sexual spores (ascospores) and asexual spores (conidia) (Figs. 4 and 5). Ascospores are formed in single-walled asci within a single perithecium covered by stromata. Eight oval to ovoid ascospores, 10 to $14 \mu \mathrm{m} \times 5.5$ to $8 \mu \mathrm{m}$, are produced per ascus (Hock et al. 1992; Liu 1973; Maublanc 1904). Ascospores are discharged through the perithecial ostiole in a mucilaginous mass (Fig. 6). A single perithecium will discharge spores repeatedly over the course of several days, occasionally producing pale cirrhi (Parbery 1963). Ascospores require a temperature range of 20 to $25^{\circ} \mathrm{C}$ for optimal germination with relative humidity $>75 \%$ and prolonged periods of leaf wetness (Bajet et al. 1994; Groves et al. 2020; Hock et al. 1989; Maublanc 1904; PereydaHernández et al. 2009). Dittrich et al. (1991) found that in laboratory studies, ascospore germination can occur in as little as $2 \mathrm{~h}$ in distilled water at $24^{\circ} \mathrm{C}$. These researchers also indicated that ascospore germination and formation of appressoria by $P$. maydis occurred between 10 and $20^{\circ} \mathrm{C}$, with appressoria forming within 12 to 24 $\mathrm{h}$, which is consistent with other members of the genus (Parbery 1963).

P. maydis can overwinter on plant residue. In Mexico, on infected corn material that was left uncovered on the field surface for 3 months, ascospores had a maximum germination rate of $3 \%$. Recent studies by Kleczewski et al. (2019) and Groves et al. (2020) showed that ascospores overwintered in the Midwest U.S. on corn residue despite harsh winter weather conditions (a low of $-34^{\circ} \mathrm{C}$ air temperature), germinating in the laboratory and infecting seedlings

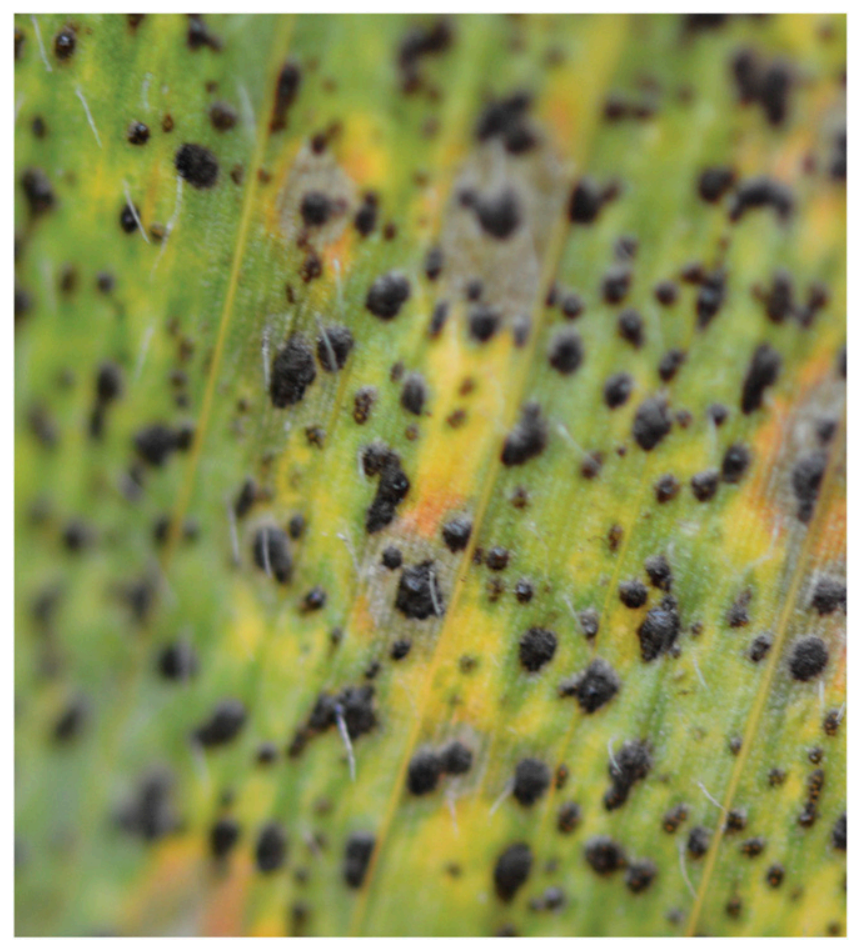

Fig. 2. Slightly raised, semicircular, dark brown to black glossy structures known as stromata are shielded by clypeus. 
under controlled conditions. Nevertheless, neither the mechanisms of overwintering nor the existence of alternative plant hosts of $P$. maydis are known (Groves et al. 2020; Mottaleb et al. 2019).

The pycnidial stage of $P$. maydis (Linochora maydis) may also be present in the form of filiform spermatia. Spermatia are 10 to $15 \mu \mathrm{m} \times$ $0.5 \mu \mathrm{m}$ and are produced in pycnidial fruiting bodies, which are often found with perithecia in stromata. According to Parbery (1967) and Müller and Samuels (1984), these spores may fulfill the role of conidia in the Phyllachora life cycle.

Microdochium spp. includes important plant pathogens, particularly on grasses and small grain cereals (Von Arx 1987). Microdochium spp. are recognized as Fusarium-like fungi due to similar spore morphology. However, the conidiogenous cells in Microdochium spp. are not phialidic as in true Fusarium species and the conidia have a truncate base rather than 'foot-cells' (Von Arx 1987). Monographella maydis (syn. Microdochium maydis E. Müll. \& Samuels) was first described in 1984 from leaf tissue from Mexico (Bajet et al. 1994; Hock et al. 1992; Müller and Samuels 1984; Von Arx 1987). Both the teleomorph and anamorph of $M$. maydis were recovered from fisheye lesions, and inoculation of corn plants naturally infected with $P$. maydis and $M$. maydis conidial suspensions caused the characteristic fisheye lesions to develop and significantly increased disease severity (Hock et al. 1992). However, a lack of methodological details in the Hock et al. (1992) study limits the credibility of these observations.

M. maydis forms single-walled asci within perithecia immersed in host tissue, eventually erupting through the epidermis. Eight fusiform ascospores, 18 to $22 \mu \mathrm{m} \times 3.5$ to $5 \mu \mathrm{m}$, containing 1 to 3 transverse septa, are produced per ascus. Conidia produced in

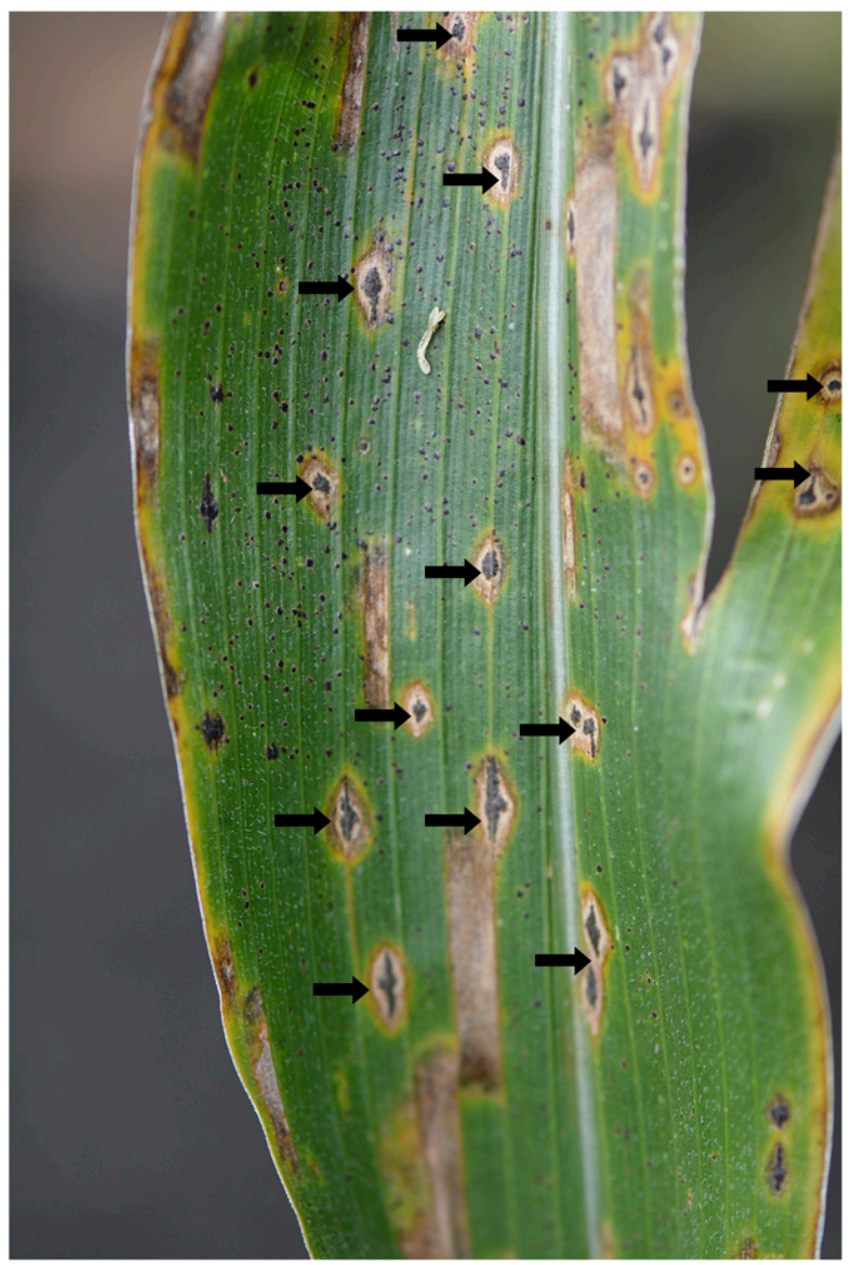

Fig. 3. Stromata can be enclosed by brown, elliptic, necrotic halos known as "fisheye lesions" (indicated by arrows). sporodochia are hyaline, elongate, mostly curved, 20 to $46 \mu \mathrm{m} \times 3$ to $4 \mu \mathrm{m}$ with 3 to 9 transverse septa. The sexual stage of the pathogen is rarely found in the field. Conidial germination was greatest at $25^{\circ} \mathrm{C}$ in darkness (Dittrich et al. 1991). In inoculation trials during this research, infection of corn with M. maydis by itself was achieved in only one of eight attempts under $38 / 18^{\circ} \mathrm{C}$ day/night temperatures and 80 to $100 \%$ relative humidity. M. maydis persists on infected crop residue, with conidia remaining viable for 109 days on detached leaves at room temperature (Hock et al. 1992).

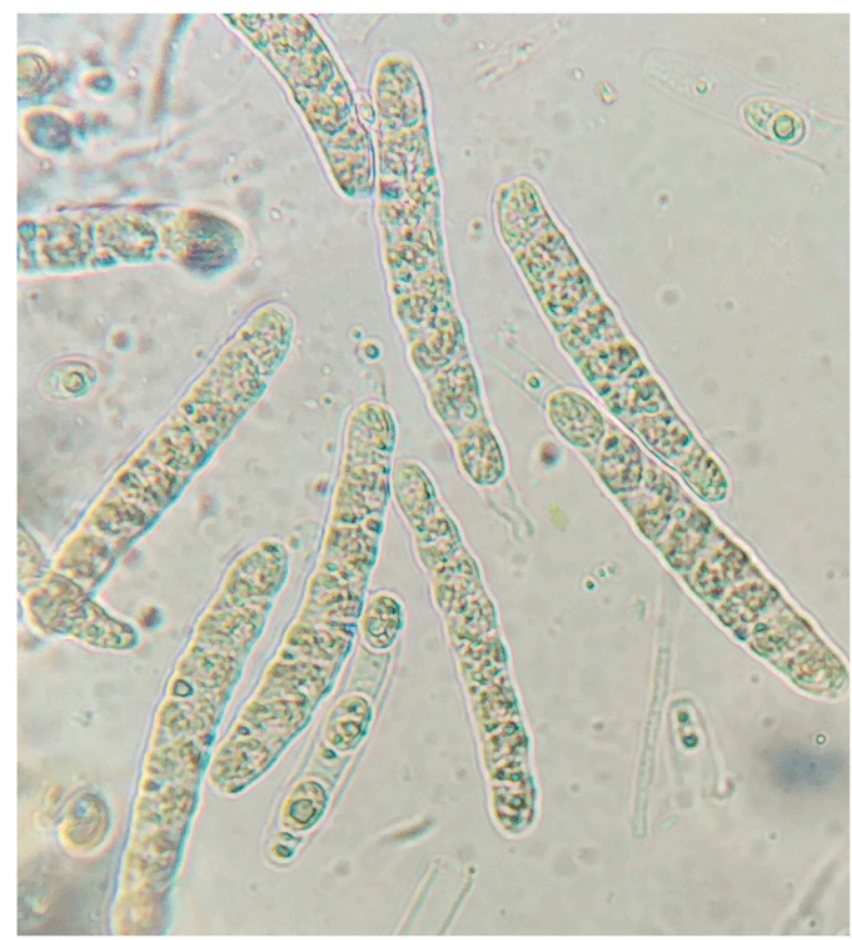

Fig. 4. Phyllachora maydis sexual spores (ascospores).

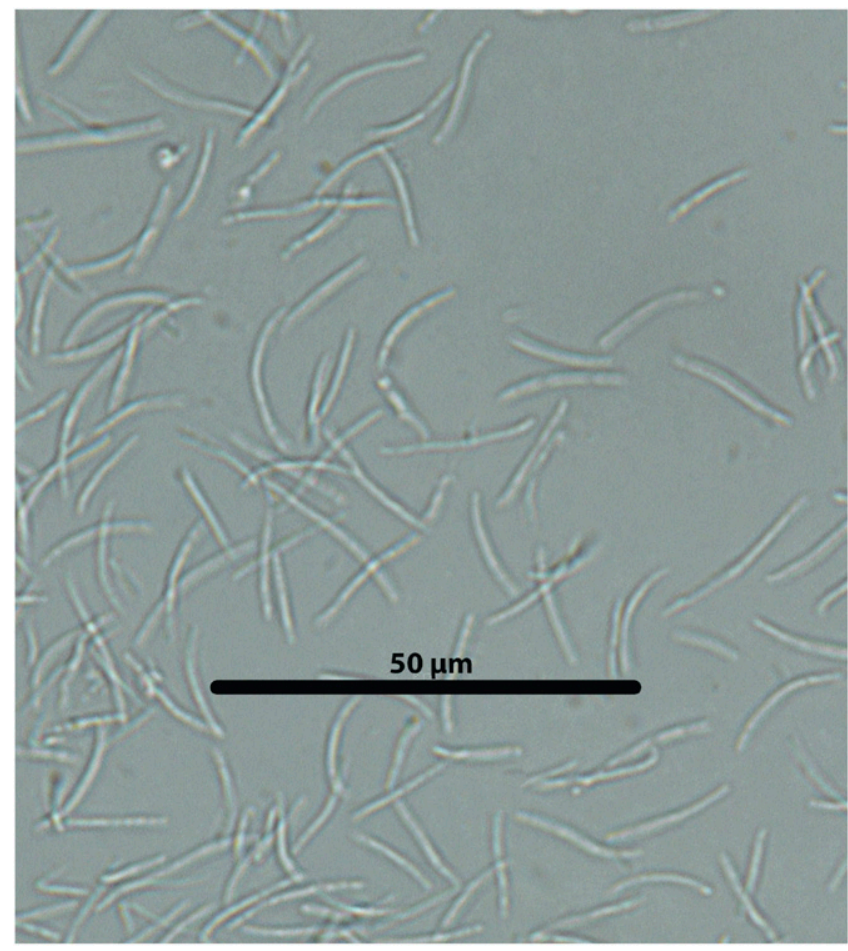

Fig. 5. Phyllachora maydis asexual spores (conidia). 


\section{Disease Cycle}

The disease cycle of tar spot is not fully understood. However, ascospores and conidia of $P$. maydis can overwinter in stromata on decaying corn leaves or residue in fields (Groves et al. 2020; Kleczewski et al. 2019). Hence, infested residue with propagules are likely the source of primary inoculum. According to Hock et al. (1992), ascospores are released from stromata and disperse either by wind or rain splash to foliage during periods of moderate temperature $\left(16\right.$ to $23^{\circ} \mathrm{C}$ ), leaf wetness duration of greater than $7 \mathrm{~h}$ per night, and relative humidity greater than $75 \%$ (Hock et al. 1995). Long-distance spore dispersal is another possible source of primary inoculum. However, ascospore dispersal has been documented only as far as $31 \mathrm{~m}$ from the source of the inoculum (Liu 1973). Ascospores infect nearby corn plants and this cycle will repeat multiple times per growing season under conducive conditions (Bajet et al. 1994; Hock et al. 1989). In the U.S., fields with no previous history of tar spot have documented tar spot symptoms first in the upper crop canopy and not in the lower canopy (A. Robertson 2019, D. Malvick 2020, personal communications). This raises questions about the possibility of longdistance dispersal. Neither the incubation period (time from inoculation to symptom development) nor latent period (time from inoculation to onset of reproductive structures) (Parlevliet 1979) has been clearly established for $P$. maydis. Preliminary data from two of our labs indicated that the latent period can be variable, but the range is usually 14

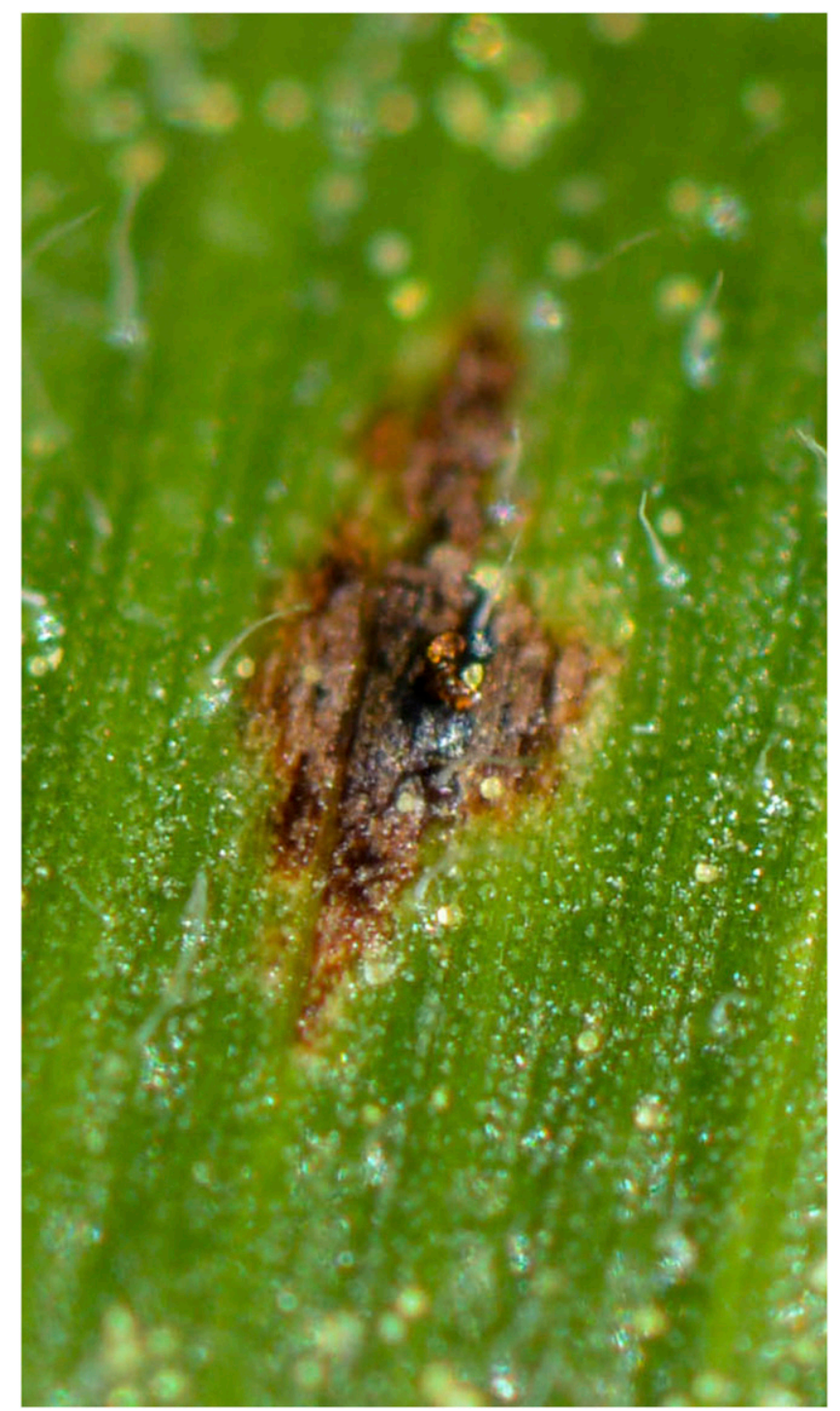

Fig. 6. Sexual spores (ascospores) of Phyllachora maydis can be discharged through a perithecial ostiole in a mucilaginous mass. to 20 days at 16 to $23^{\circ} \mathrm{C}$ (Cruz and Kleczewski, unpublished). Latent periods can be significantly influenced by growing degree days (GDD) and other factors, including host resistance level (Précigout et al. 2020), so it is likely that variability in latency of $P$. maydis is related to these factors. Symptoms of tar spot are observed 14 days after infection and new ascospores are produced in stromata soon thereafter (Hock et al. 1995). A schematic representation of the presumed disease cycle of tar spot in the U.S. is shown in Figure 7.

\section{Geographical Distribution}

P. maydis is endemic to parts of Mexico and Central and South America (Fig. 8, Table 1), where it was apparently restricted for over 100 years (Cline 2019; Hock et al. 1995). However, in 2015, it was detected for the first time in the continental U.S. and has spread significantly since then (Bissonnette 2015; Ruhl et al. 2016). P. maydis is now established in the U.S. in Illinois, Indiana, Iowa, Michigan, Minnesota, Missouri, Ohio, Wisconsin, and Florida (Fig. 8) (Bissonnette 2015; Dalla Lana et al. 2019; Malvick et al. 2020; McCoy et al. 2018; Ruhl et al. 2016). Multiple pathways have been proposed for the introduction of P. maydis into the U.S. (Mottaleb et al. 2019; Ruhl et al. 2016). Pathogenic microorganisms and pests can be introduced as contaminants of plants and plant products traded internationally (Brasier 2008). Although P. maydis is not known to be seedborne, imported grains contaminated with leaf/husk residue can be a source of inoculum (Richardson 1990).

\section{Molecular Diagnostics}

The biotrophic nature of $P$. maydis makes it difficult to study in the laboratory, as it has never been cultured on synthetic medium (Müller and Samuels 1984). The use of genetic technologies such as DNA diagnostics (amplification and sequencing) can compensate for this difficulty and give us a better understanding of the fungus. Prior to 2015, none of the Phyllachora spp. genomes had been sequenced, and hence no comparative sequence data were available in GenBank, NIH genetic sequence database, or the U.S. National Fungus Collection (BPI) (Ruhl et al. 2016). Phyllachora spp. were mainly diagnosed via symptom and morphological characters (Hock et al. 1995; Maublanc 1904; Müller and Samuels 1984; Parbery 1963; Ruhl et al. 2016). However, due to the recent documentation of $P$. maydis in the U.S., molecular diagnostic data are now available in GenBank and the NIH genetic sequence database. DNA was extracted from stromata, aseptically removed from corn leaves collected in each of the affected U.S. states, sequenced, and deposited in the U.S. National Fungus Collection (BPI) (McCoy et al. 2018). Currently, sequences for the internal transcribed spacer (ITS) regions of the ribosomal RNA gene are the only genetic sequences available for $P$. maydis in GenBank (McCoy et al. 2018; Ruhl et al. 2016). There are 67 specimen records found for $P$. maydis and its synonyms in the U.S. National Fungus Collection (BPI), of which only five specimens were deposited based on molecular identification via ITS sequence confirmation. The current ITS sequences reported in GenBank for identification of $P$. maydis are listed in Table 2.

A draft genome sequence of $P$. maydis (Telenko et al. 2020) was recently published, which will provide an important resource for further studies on the origin of $P$. maydis in the U.S., population structure, genetic diversity, and phylogenetic relationships among other Phyllachora spp.

In a recent paper, phylogenetic relationships among species in the order Phyllachorales were inferred based on Bayesian analysis incorporating sequence information from five molecular characters, namely 1) nuclear large subunit ribosomal DNA (nrLSU rDNA), 2) nuclear small subunit ribosomal DNA (nrSSU rDNA), 3) internal transcribed spacer ribosomal DNA (ITS rDNA), and the protein coding genes 4) DNA-directed RNA polymerase II subunit 2 (RPB2), and 5) elongation factor 1-alpha (TEF1) (Mardones et al. 2017). It is interesting to note that $P$. maydis showed similarity with all five of the molecular characteristics considered and appears to be most closely related to $P$. graminis (Mardones et al. 2017).

A study by Hernández-Restrepo et al. (2016) used ITS, TEF1, $\mathrm{RPB} 2$, and nrSSU rDNA regions to construct a phylogenetic tree of the Phyllachorales, validating the use of these regions and generating 
sequences that could be adapted for future work with $P$. maydis. To date, there are three phylogenetic trees published with similar loci, but for the Phyllachora portion only the ITS gene was used, and species distinctions within the genus still need to be resolved.

A recent re-evaluation of Monographella considered four loci for use in taxonomic and phylogenetic studies of this genus. Of the four, the partial beta-tubulin gene region was found to be the most informative, with RPB2 also recommended. The TEF1 gene has also been used to differentiate between Monographella spp. Unfortunately, no genetic data for M. maydis exists in public databases (HernándezRestrepo et al. 2016).

\section{Genetic Basis of Host Resistance and Breeding for Resistance}

Deploying host resistance is potentially both an economical and effective means of managing tar spot. A range of reactions to $P$.

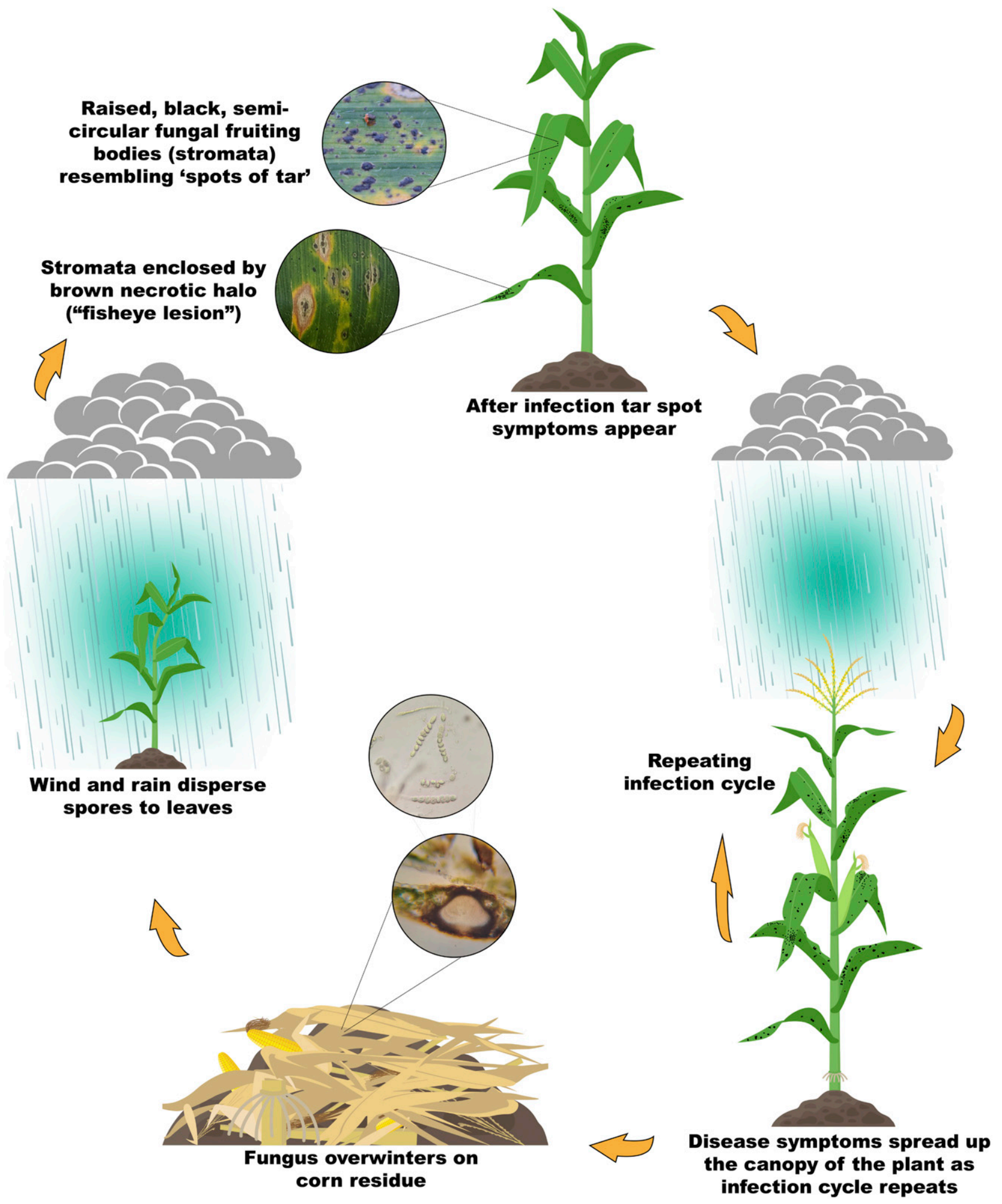

Fig. 7. Schematic representation of the presumed tar spot disease cycle in the United States. Phyllachora maydis is capable of overwintering in corn residue and generating secondary infections. Symptoms of tar spot can be observed 14 days after infection and new ascospores are produced in stromata soon thereafter. Ascospore dispersal has been documented to only as far as $31 \mathrm{~m}$ from the source. However, anecdotal evidence suggests that long-distance dispersal may also occur. 
maydis have been observed in diverse corn germplasm, indicating that a range of resistance to tar spot exists (Cao et al. 2017; Ceballos and Deutsch 1992; Mahuku et al. 2016). Furthermore, the heritability of tar spot resistance is moderate to high, indicating that breeding to develop resistant populations is possible (Cao et al. 2017).

The genetic architecture of tar spot resistance is complex, but a single large-effect locus for resistance has been consistently detected (Cao et al. 2017; Ceballos and Deutsch 1992; Mahuku et al. 2016). An early study utilizing three segregating biparental populations found resistance to symptoms caused by $P$. maydis to be highly heritable and dominant in nature (Ceballos and Deutsch 1992). More recently, a large-effect quantitative trait locus (QTL) located in chromosomal bin 8.03 , referred to as $q$ Rtsc $8-1$, was consistently detected across multiple tropical/subtropical populations of corn screened in several locations across Central and South America (Cao et al. 2017; Mahuku et al. 2016). When detected, qRtsc $8-1$ accounted for 18 to $43 \%$ of the observed phenotypic variation in disease severity (Cao et al. 2017; Mahuku et al. 2016). It is interesting to note that the most significant association

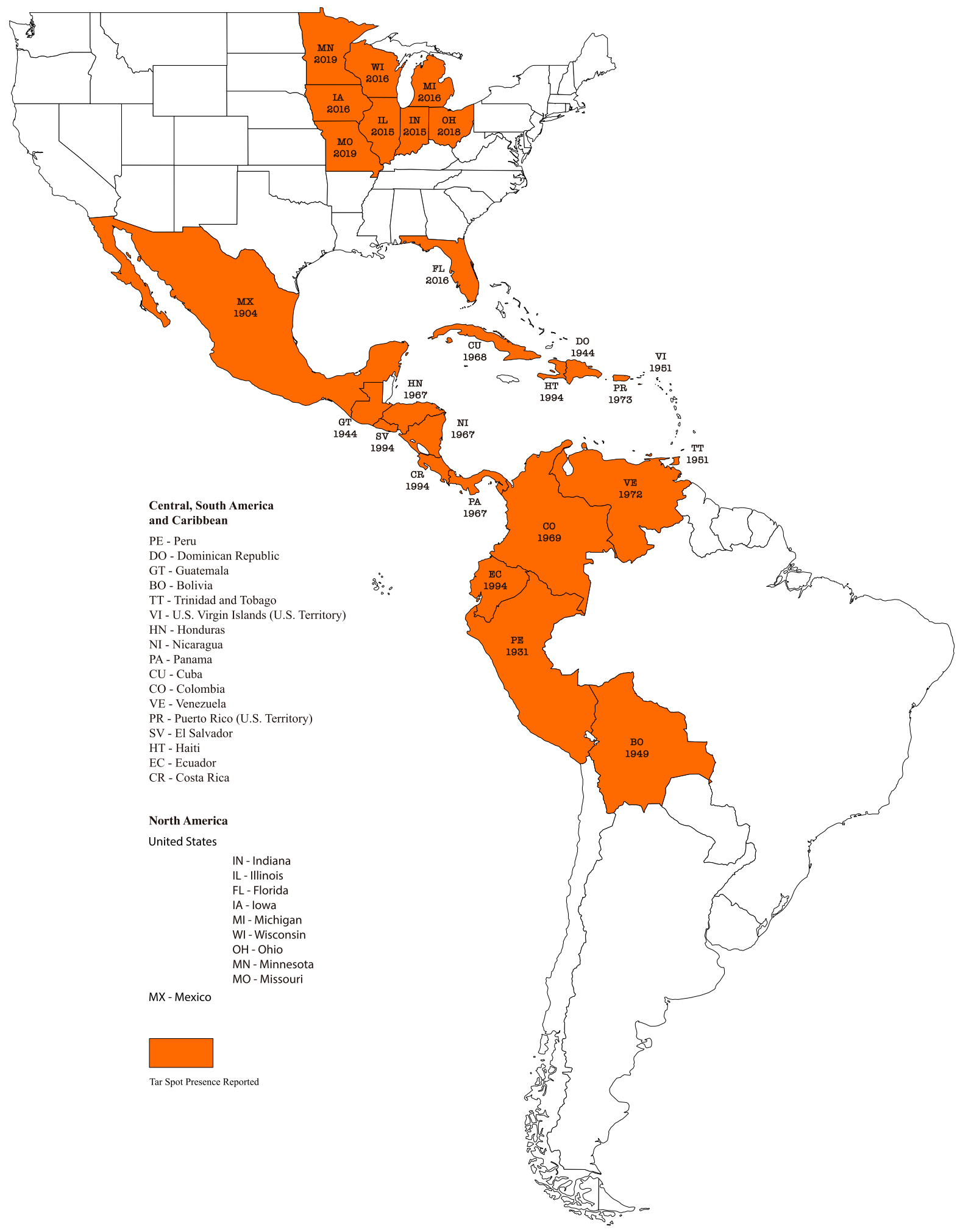

Fig. 8. Phyllachora maydis was reported for the first time in Mexico in 1904 and is currently present in 16 additional countries. In the U.S., it was first reported in 2015 , and is now established in nine states. 
identified by Mahuku et al. (2016) in a genome-wide association mapping study was with a leucine-rich repeat receptor-like encoding gene, which would be consistent with a major resistance gene. Several haplotypes were identified in $q$ Rtsc8-1 that increased resistance (Mahuku et al. 2016). Together, these results indicate that marker-assisted selection for resistant $q$ Rtsc $8-1$ haplotypes might be an effective strategy for developing tar spot resistant varieties.

\section{Hybrid Reaction and Susceptibility to Tar Spot}

A study by Telenko et al. (2019) evaluated corn hybrid reactions to tar spot during the 2018 U.S. Midwest epidemic. In that study, all hybrids rated were susceptible to tar spot pathogen. Severity of leaf symptoms ranged from minor (1 to $15 \%$ ) to severe (40 to $50 \%$ ). Data from these hybrid trials demonstrated a range in hybrid susceptibility and reaction to tar spot, where every $1 \%$ increase in tar spot severity resulted in an estimated 21.5 to $91.5 \mathrm{~kg} / \mathrm{ha}$ loss (Telenko et al. 2019).

\section{Future Outlook and Challenges}

Tar spot has become a high-profile emerging disease in the U.S. due to its recent identification and spread, documented impact on corn yields, and the threat it poses to corn production. Mottaleb et al. (2019) indicated that tar spot can become established throughout the U.S. corn belt. Unfortunately, there is a general lack of information about this pathosystem.

For instance, currently there is no evidence of M. maydis association with fisheye lesions in the U.S. Hence, future research that surveys a large collection of tar spot-infected corn from different regions would help test previously established hypotheses and provide critical information to understand this disease and fisheye symptom development. Hypotheses that may explain these observations are that fisheye lesions are a result of $P$. maydis infection alone, and/or specific pathogen $\times$ host $\times$ environmental conditions result in their development. Alternatively, fisheye lesions may be caused by a different fungus that was incorrectly identified as M. maydis in previous studies. This hypothesis is difficult to confirm as no vouchers of $M$. maydis exist from the initial species description and no molecular data exist for M. maydis (Hernández-Restrepo et al. 2016). Monographella spp. previously were defined as members of the genus Fusarium. Could certain local species of Fusarium be responsible for fisheye development? Finally, an unidentified organism may be the reason for the development of fisheyes.

The events underlying P. maydis emergence in the U.S. are currently unknown. Thus, there is need to investigate the genetic diversity and population structure of $P$. maydis. This information will help determine whether $P$. maydis was an endemic pathogen already present in the U.S. that underwent genetic changes that resulted in the ability to infect corn, or whether $P$. maydis was introduced to the U.S. by movements of people, crop materials, or weather systems.

Developing effective and long-lasting prevention strategies is key for tar spot management. For that reason, we need to increase the current understanding of pathogen biology and disease epidemiology, which would include a better understanding of changes in disease intensity over time and space. Visual tar spot surveillance methods and diagrammatic scales that partition severity into predetermined stroma or fisheye/necrotic severity classes are available. However, these diagrammatic scales are based on leaf sections rather than the whole leaf; this might present a challenge as symptoms might not be uniform across the leaf blade. Although the development and diversity of tar spot symptoms has not been characterized thoroughly, such work is foundational for disease phenotyping. The information generated is key to developing epidemiological criteria to support breeding tactics (Fernandez-Campos et al. 2020) against this disease. Autonomous aerial vehicles offer an alternative for tar spot phenotyping since they can be equipped with a range of sensors that measure spectral reflectance (Loladze

Table 1. Geographical distribution of tar spot based on available reports

\begin{tabular}{lcl}
\hline Continent/country & Year documented & \multicolumn{1}{c}{ Source } \\
\hline Central, South America, and Caribbean & & \\
Peru & 1931 & Abbott (1931) \\
Dominican Republic, Guatemala & 1944 & Bajet et al. (1994); Orton (1944) \\
Bolivia & 1949 & Bajet et al. (1994); Stevenson and Cárdenas (1949) \\
Trinidad and Tobago & 1951 & Baker and Dale (1951) \\
U.S. Virgin Islands & 1951 & Stevenson (1975) \\
Honduras, Nicaragua, Panama & 1967 & McGuire and Crandall (1967) \\
Cuba & 1968 & Arnold (1986) \\
Colombia & 1969 & Bajet et al. (1994); Castaño (1969) \\
Venezuela & 1972 & Bajet et al. (1994); Malaguti and Subero (1972) \\
Puerto Rico & 1973 & Bajet et al. (1994); Liu (1973) \\
El Salvador, Haiti, Ecuador, Costa Rica & 1994 & Bajet et al. (1994) \\
North America & & \\
Mexico & 1904 & Maublanc (1904); Hock et al. (1989) \\
U.S. (Indiana and Illinois) & 2015 & Bissonnette (2015); Ruhl et al. (2016) \\
U.S. (Florida, Iowa, Michigan, Wisconsin) & 2016 & McCoy et al. (2018) \\
U.S. (Ohio) & 2018 & Dalla Lana et al. (2019) \\
U.S. (Minnesota, Missouri) & 2019 & Athey 2020; Bissonnette (personal communication); Malvick et al. (2020) \\
\hline
\end{tabular}

Table 2. GenBank's available sequences for Phyllachora maydis identification

\begin{tabular}{lcc}
\hline Collection location & (NCBI voucher) GenBank ID & Source \\
\hline Indiana & (BPI 893231) No. KU184459 & Ruhl et al. (2016) \\
Iowa & (BPI 910561) No. MG881848.1 & McCoy et al. (2018) \\
Michigan & (BPI 910562) No. MG881847.1 & McCoy et al. (2018) \\
Ohio & (18AP065) No. MK184990 & Dalla Lana et al. (2019) \\
Wisconsin & (BPI 910560) No. MG881846 & McCoy et al. (2018) \\
\hline
\end{tabular}


et al. 2019; Mahlein et al. 2018). Several vegetation indices obtained from multispectral and thermal data have been correlated with tar spot severity and losses of grain yield in the absence of fungicide treatment (Loladze et al. 2019). Future studies in this area should determine whether remote sensing platforms are capable of describing temporal and spatial dynamics of the disease (Gongora-Canul et al. 2020).

Effective management strategies for tar spot are limited and are based on what is known of tar spot in Mexico, Central America, and South America (Kleczewski et al. 2019). Limited field data are available from the U.S. Kleczewski et al. (2019) proposed that management strategies need to target environmental conditions, fungal populations, hybrid genetics, and cropping systems associated with each region. Tar spot management strategies have been recommended but remain limited in the U.S. due to the recent appearance of this pathogen. These strategies include (1) avoiding highly susceptible hybrids, (2) considering application of fungicides with mixed mode of action at appropriate timing close to the onset of the epidemic, (3) managing irrigation, (4) rotating crops to allow P. maydis-infected residue to decompose, and (5) removing residue from fields (Kleczewski et al. 2019; Telenko et al. 2019). Though fungicides are available for managing tar spot, the optimum timing and number of applications needed if an early epidemic occurs is not well established. Teams are also working on the development of a reliable protocol for artificial inoculations under controlled environments, and to determine economically sound management options for combatting tar spot.

Host resistance will become an important tool for control of tar spot. Little is known about resistance in germplasm adapted to the U.S. and whether previously identified QTLs will be effective against $P$. maydis populations in the U.S. Furthermore, genomic selection is a powerful tool that can take advantage of many smalleffect loci to develop resistant lines (Meuwissen et al. 2001; Poland and Rutkowski 2016). Genomic prediction models had moderate-to-high prediction accuracy for tar spot, showing promise that genomic selection may be an effective method to improve tar spot resistance in breeding programs (Cao et al. 2017).

We believe that the development of effective management strategies for this understudied pathogen requires increased understanding of its biology and epidemiology, and developing and deploying rapid diagnostic methods, effective disease weather models and surveillance, and resistant germplasm for regions at risk.

\section{Literature Cited}

Abbott, E. 1931. Further notes on plant diseases in Peru. Phytopathology 21: 1061-1071.

Arnold, G. R. W. 1986. Lista de Hongos Fitopatogenos de Cuba. Editorial Cientifico-Tecnica, Havana, Cuba.

Athey, S. 2020. Emerging diseases in Missouri corn, soybeans. Farm Talk Newspaper, Parsons, KS. https://www.farmtalknewspaper.com/news/emerging-diseases-inmissouri-corn-soybeans/article_fe96d578-41e4-11ea-a20a-9bbea678228e.html

Bajet, N. B., Renfro, B. L., and Carrasco, J. M. V. 1994. Control of tar spot of maize and its effect on yield. Int. J. Pest Manage. 40:121-125.

Baker, R., and Dale, W. T. 1951. Fungi of Trinidad and Tobago. Mycological Papers 33, Commonwealth Mycological Institute, Kew, U.K.

Bissonnette, S. 2015. Corn disease alert: new fungal leaf disease "tar spot" Phyllachora maydis identified in 3 northern Illinois counties. The Bulletin: Pest Management and Crop Development Information for Illinois. http:// bulletin.ipm.illinois.edu/?p=3423. Accessed 1 Dec 2019 .

Brasier, C. M. 2008. The biosecurity threat to the UK and global environment from international trade in plants. Plant Pathol. 57:792-808.

Cannon, P. F. 1991. A revision of Phyllachora and some similar genera on the host family Leguminosae. Mycol. Pap. 163:302.

Cao, S., Loladze, A., Yuan, Y., Wu, Y., Zhang, A., Chen, J., Huestis, G., Cao, J., Chaikam, V., Olsen, M., Prasanna, B., San Vicente, F., and Zhang, X. 2017. Genome-wide analysis of tar spot complex resistance in maize using genotype-by-sequencing SNPs and whole genome prediction. Plant Genome 10(2):1-14.

Carson, M. L. 1999. Diseases of minor importance or limited occurrence. Pages 23-25 in: Compendium of Corn Diseases. D. G. White, ed. American Phytopathological Society, St Paul, MN.

Castaño, A. 1969. Mancha de asfalto (tar spot) de la hoja del maíz. Agric. Trop. 25 : 332.

Ceballos, H., and Deutsch, J. A. 1992. Inheritance of resistance to tar spot complex in maize. Phytopathology 82:505-512.
CIMMYT. 2003. Maize Diseases: A guide for field identification. 4th Edition. International Maize and Wheat Improvement Center, Mexico, D.F., Mexico. https://afghanag.ucdavis.edu/grain-field-crops/files/maize-diseases.pdf

Cline, E. 2019. Phyllachora maydis. U.S. National Fungus Collections, ARS, USDA. Retrieved November 1, 2019, from https://nt.ars-grin.gov/sbmlweb/ fungi/nomenSheets.cfm

Dalla Lana, F., Plewa, D. E., Phillippi, E. S., Garzonio, D., Hesterman, R. Kleczewski, N. M., and Paul, P. A. 2019. First report of tar spot of Maize (Zea mays), caused by Phyllachora maydis, in Ohio. Plant Dis. 103:1780.

Dittrich, U., Hock, J., Kranz, J., and Renfro, B. L. 1991. Germination of Phyllachora maydis ascospores and conidia of Monographella maydis. Cryptogam. Bot. 2:214-218.

Fernandez-Campos, M., Gongora-Canul, C., Das., S., Kabir, M., Valent, B., and Cruz, C. D. 2020. Epidemiological criteria to support breeding tactics against the emerging, high-consequence wheat blast disease. Plant Dis. doi.org/ 10.1094/PDIS-12-19-2672-RE

Gongora-Canul, C., Salgado, J. D., Singh, D., Cruz, A. P., Cotrozzi, L., Couture, J., Rivadeneira, M. G., Cruppe, G., Valent, B., Todd, T., Poland, J., and Cruz, C. D. 2020. Temporal dynamics of wheat blast epidemics and disease measurements using multispectral imagery. Phytopathology 110:393-405.

Groves, C. L., Kleczewski, N. M., Telenko, D. E. P., Chilvers, M. I., and Smith, D. L. 2020. Phyllachora maydis ascospore release and germination from overwintered corn residue. Plant Health Prog. 21:26-30.

Hernández-Restrepo, M., Groenewald, J. Z., and Crous, P. W. 2016. Taxonomic and phylogenetic re-evaluation of Microdochium, Monographella and Idriella. Persoonia 36:57-82.

Hock, J. 1989. Requisitos ambientales para el desarrollo del "complejo mancha de asfalto" que ataca al maíz en Mexico. Page 8 in: Congreso ASCOLFI 10, Cali, Colombia, 10-14 July 1989

Hock, J., Dittrich, U., Renfro, B. L., and Kranz, J. 1992. Sequential development of pathogens in the maize tarspot disease complex. Mycopathologia 117:157-161.

Hock, J., Kranz, J., and Renfo, B. L. 1995. Studies on the epidemiology of the tar spot disease complex of maize in Mexico. Plant Pathol. 44:490-502.

Hock, J., Kranz, J., and Renfro, B. 1989. El complejo "mancha de asfalto" de maíz: Su distribucción geográfica, requisitos ambientales e importancia económica en México. Rev. Mex. Fitopatol. 7:129-135.

Kleczewski, N. M., Chilvers, M., Mueller, D. S., Plewa, D., Robertson, A. E., Smith, D. L., and Telenko, D. E. 2019. Corn disease management: Tar spot. CPN 2012-W. Crop Protection Network. https://doi.org/10.31274/cpn-20190620-008

Liu, L.-J. 1973. Incidence of tar spot disease of corn in Puerto Rico. J. Agric. Univ. P. R. 42:211-216.

Loladze, A., Rodrigues, F. A., Jr., Toledo, F., San Vicente, F., Gérard, B., and Boddupalli, M. P. 2019. Application of remote sensing for phenotyping tar spot complex resistance in Maize. Front. Plant Sci. 10:552.

Mahlein, A. K., Kuska, M. T., Behmann, J., Polder, G., and Walter, A. 2018. Hyperspectral sensors and imaging technologies in phytopathology: state of the art. Annu. Rev. Phytopathol. 56:535-558.

Mahuku, G., Chen, J., Shrestha, R., Narro, L. A., Osorio-Guerrero, K. V., Arcos, A. L., and Xu, Y. 2016. Combined linkage and association mapping identifies a major QTL (qRtsc8-1), conferring tar spot complex resistance in maize. Theor. Appl. Genet. 129:1217-1229.

Malaguti, G., and Subero, L. J. 1972. Mancha de asfalto del maiz. Agron. Trop. 22 443-445.

Malvick, D. K., Plewa, D. E., Lara, D., Kleczewski, N. M., Floyd, C. M., and Arenz, B. E. 2020. First report of tar spot of corn caused by Phyllachora maydis in Minnesota. Plant Dis. 104:1865.

Mardones, M., Trampe-Jaschik, T., Oster, S., Elliott, M., Urbina, H., Schmitt, I., and Piepenbring, M. 2017. Phylogeny of the order Phyllachorales (Ascomycota, Sordariomycetes): among and within order relationships based on five molecular loci. Persoonia 39:74-90.

Maublanc, A. 1904. Espéces nouvelles de champignons inferieurs. Bull. Soc. Mycol. Fr. 20:72-74.

McCoy, A. G., Romberg, M. K., Zaworski, E. R., Robertson, A. E., Phibbs, A., Hudelson, B. D., Smith, D. L., Beiriger, R. L., Raid, R. N., Byrne, J. M. and Chilvers, M. I. 2018. First report of tar spot on corn (Zea mays) caused by Phyllachora maydis in Florida, Iowa, Michigan, and Wisconsin. Plant Dis. 102:1851.

McCoy, A. G., Roth, M. G., Shay, R., Noel, Z. A., Jayawardana, M. A., Longley, R. W., Bonito, G., and Chilvers, M. I. 2019. Identification of fungal communities within the tar spot complex of corn in Michigan via nextgeneration sequencing. Phytobiomes J. 3:235-243.

McGuire, J. U., and Crandall, B. S. 1967. Survey of insect pests and plant diseases of selected food crops of Mexico, Central America and Panama. U.S Department of Agriculture, International Agricultural Development Service.

Meuwissen, T. H., Hayes, B. J., and Goddard, M. E. 2001. Prediction of total genetic value using genome-wide dense marker maps. Genetics 157: 1819-1829.

Mottaleb, K. A., Loladze, A., Sonder, K., Kruseman, G., and San Vicente, F. 2019. Threats of tar spot complex disease of maize in the United States of America and its global consequences. Mitig. Adapt. Strategies Glob. Change 24:281-300.

Mueller, D., Wise, K., and Sisson, A. 2018. Corn disease management: Corn disease loss estimates from the United States and Ontario, Canada -2017. CP 200717 W. Crop Protection Network. https://doi.org/10.31274/cpn-20190620-040 
Müller, E., and Samuels, J. G. 1984. Monographella maydis: sp. nov. and its connection to the tar-spot disease of Zea mays. Nova Hedwigia 40:113-121.

Orton, C. R. 1944. Graminicolous species of Phyllachora in North America. Mycologia 36:18-53.

Parbery, D. G. 1963. Studies on graminicolous species of Phyllachora Fckl. I. Ascospores - their liberation and germination. Aust. J. Bot. 11:117-130.

Parbery, D. G. 1967. Studies on graminicolous species of Phyllachora Nke. in Fck1. V. A taxonomic monograph. Aust. J. Bot. 15:271-375.

Parbery, D. G. 1971. Studies on graminicolous species of Phyllachora Nke. in Fckl. VI. Additions and corrections to part V. Aust. J. Bot. 19:207-235.

Parlevliet, J. E. 1979. Components of resistance that reduce the rate of epidemic development. Annu. Rev. Phytopathol. 17:203-222.

Pereyda-Hernández, J., Hernández-Morales, J., and Sandoval-Islas, J. S. 2009. Etiología y manejo de la mancha de asfalto (Phyllachora maydis Maubl.) del maíz en Guerrero, México. Agrociencia 43:511-519.

Poland, J. and Rutkoski, J. 2016. Advances and challenges in genomic selection for disease resistance. Annu. Rev. Phytopathol. 54:79-98.

Précigout, P. A., Claessen, D., Makowski, D., and Robert, C. 2020. Does the latent period of leaf fungal pathogens reflect their trophic type? A meta-analysis of biotrophs, hemibiotrophs, and necrotrophs. Phytopathology 110:345-361.
Richardson, M. J. 1990. An annotated list of seed-borne diseases, 4th Ed. International Seed Testing Association, Zurich, Switzerland.

Ruhl, G., Romberg, M. K., Bissonnette, S., Plewa, D., Creswell, T., and Wise, K. A. 2016. First report of tar spot on corn caused by Phyllachora maydis in the United States. Plant Dis. 100:1496.

Stevenson, J. A. 1975. The fungi of Puerto Rico and the American Virgin Islands. Contribution of Reed Herbarium, no. 23, Baltimore, MD.

Stevenson, J. A., and Cárdenas, M. 1949. Lista Preliminar de los Hongos de Bolivia. Lilloa 21:77-134

Telenko, D. E. P., Chilvers, M. I., Kleczewski, N., Smith, D. L., Byrne, A. M., Devillez, P., Diallo, T., Higgins, R., Joos, D., Kohn, K., Lauer, J., Mueller, B., Singh, M. P., Widdicombe, W. D. and Williams, L. A. 2019. How tar spot of corn impacted hybrid yields during the 2018 Midwest epidemic. Crop Protection Network. https://doi.org/10.31274/cpn-20190729-002.

Telenko, D. E. P., Ross, T. J., Shim, S., Wang, Q., and Singh, R. 2020. Draft genome sequence resource for Phyllachora maydis - an obligate pathogen that causes tar spot of corn with recent economic impacts in the United States. Mol. Plant-Microbe Interact. doi.org/10.1094/MPMI03-20-0075-A

Von Arx, J. A. 1987. Plant pathogenic fungi. Nova Hedwigia 87:1-288.

\section{J. Valle-Torres}

Zamorano University, San Antonio de Oriente, Fco. Morazán, Honduras

\section{T. J. Ross}

Department of Botany and Plant Pathology, Purdue University, West Lafayette, IN 47907, U.S.A.

\section{Plewa}

Department of Crop Sciences, University of Illinois, Urbana, IL 61801, U.S.A.

\section{C. Avellaneda}

Zamorano University, San Antonio de Oriente, Fco. Morazán, Honduras

\section{J. Check}

Department of Plant, Soil and Microbial Sciences, Michigan State University, East Lansing, MI 48824, U.S.A.

\section{I. Chilvers}

Department of Plant, Soil and Microbial Sciences, Michigan State University, East Lansing, Ml 48824, U.S.A.

\section{A. P. Cruz}

Department of Botany and Plant Pathology, Purdue University, West Lafayette, IN 47907, U.S.A.

\section{F. Dalla Lana}

Department of Plant Pathology, The Ohio State University, Wooster, OH 44691, U.S.A.

\section{Groves}

Department of Plant Pathology, University of Wisconsin-Madison, Madison, WI 53706, U.S.A.

\section{Gongora-Canul}

Department of Botany and Plant Pathology, Purdue University, West Lafayette, IN 47907, U.S.A.

\section{Henriquez-Dole}

Zamorano University, San Antonio de Oriente, Fco. Morazán, Honduras

\section{T. Jamann}

Department of Crop Sciences, University of Illinois, Urbana, IL 61801, U.S.A.

\section{N. Kleczewski}

Department of Crop Sciences, University of Illinois, Urbana, IL 61801, U.S.A.

\section{S. Lipps}

Department of Crop Sciences, University of Illinois, Urbana, IL 61801, U.S.A.

\section{Malvick}

Department of Plant Pathology, University of Minnesota, St. Paul, MN 55108, U.S.A.

\section{A. G. McCoy}

Department of Plant, Soil and Microbial Sciences, Michigan State University, East Lansing, MI 48824, U.S.A.

\section{S. Mueller}

Department of Plant Pathology and Microbiology, lowa State University, Ames, IA 50011, U.S.A

\section{P. A. Paul}

Department of Plant Pathology, The Ohio State University, Wooster, OH 44691, U.S.A.

\section{Puerto}

Zamorano University, San Antonio de Oriente, Fco. Morazán, Honduras

\section{Schloemer}

Department of Botany and Plant Pathology, Purdue University, West Lafayette, IN 47907, U.S.A. 


\section{R. N. Raid}

Department of Plant Pathology and Microbiology, lowa State University, Ames, IA 50011, U.S.A.

\section{A. Robertson}

Department of Plant Pathology and Microbiology, lowa State University, Ames, IA 50011, U.S.A.

\section{E. M. Roggenkamp}

Department of Plant, Soil and Microbial Sciences, Michigan State University, East Lansing, Ml 48824, U.S.A.

\section{L. Smith}

Department of Plant Pathology, University of Wisconsin-Madison, Madison, WI 53706, U.S.A.

\section{E. P. Telenko}

Department of Botany and Plant Pathology, Purdue University, West Lafayette, IN 47907, U.S.A.

\section{D. Cruz}

Department of Botany and Plant Pathology, Purdue University, West Lafayette, IN 47907, U.S.A. 